\title{
Exhibiting the Nation: Indigenousness in Chile's National Museums*
}

\author{
Magdelena Gil* Columbia University, New York
}

\begin{abstract}
This article describes the history of Chile's national museums, focusing in particular on their exhibition of indigenous cultures. Three museums are considered: the National Museum of Natural History (originally the National Museum); the National Museum of Fine Arts; and the National Museum of History. Using museum catalogues, visitor's guides and bulletins as sources, this research traces the role given to indigenousness in the museums' exhibitions through time. Initially, the 'Indian' was presented as either part of the territory conquered by Chileans, or as not part of Chilean culture at all. By the twentieth century, however, a new narrative emerged which recognizes the indigenous people as the 'pre-historic' inhabitants of Chile. Most recently, a more complex narrative presents Chile as a blending of races and cultures. Overall, we see that today each museum continues to see nationhood as something that is monolithic, allowing little place for indigenous people beyond mestizaje (blending of 'races').
\end{abstract}

Key words: indigenous, exhibitions, Latin America, national identity.

\section{Introduction}

Today, exhibiting the nation has increasingly become a challenge of representing diversity, reflecting the museum as an important field for the politics of cultural recognition (Bennett 1995; Herle 1997; Murphy 2005; McLean 2007; Sleeper-Smith 2009). When museums choose to visualize or obscure groups they greatly influence perceptions of nationhood, not only in the eyes of those looking in on the culture from other nations, but for nationals as well. In Latin America, museums are principally financed by the state (Garcia Canclini 1990), and yet, the representation of some groups, including the indigenous, peasants and Afrolatinos, have repeatedly been found lacking (González de Oleaga et al. 2011; Sepulveda dos Santos 2005; Galindo Castro 2005). This research shows that Chile is no exception in this regard.

In this article, I present the history of Chile's national museums and their exhibitions through time. Although there are more than 200 public museums in Chile (Trampe 2007), I argue that politics of identity take a most pronounced form in the three national museums: the Museo Nacional de Historia Natural (National Museum of Natural History); the Museo Nacional de Bellas Artes (National Museum of Fine Arts); and the Museo Histórico Nacional (National Museum of History). Out of the 25 state-led museums administered by the Dirección de Bibliotecas, Archivos y Museos (Office of Libraries, Archives and Museums, DIBAM), these three are not only the largest in size by far, but they are also the most high-profile, as is reflected by the fact that they are the only museums labeled as 'National' in Chile, and the only ones to be included in the law that created DIBAM (Congreso Nacional de Chile 1929). Overall, these three museums share a particular responsibility for exhibiting Chileanness for both an international audience and Chileans themselves to see.

My research focuses on the display of indigenous cultures and their role in defining what it means to be Chilean. Using primary and secondary sources, I discuss how social and political changes have shaped the museums' narration of Chileanness, and particularly the position given to indigenous cultures in this definition. As we will see, narratives concerning indigenous 
people have changed markedly throughout the history of these museums. The 'Indian' was first presented as part of the territory, projecting a view of Chileans as completely distinct from indigenousness. A second narrative, led by the National Museum of Art, does not consider the indigenous at all, whereas - entering the nineteenth century - a third narrative exhibits the indigenous as the pre-historical inhabitants of Chile (but is oblivious to contemporary indigenous groups). Finally, a more recent narrative presents Chileanness as mestizo, a blending of races and cultures. Although these different narratives do appear consecutively in the museum sphere, a new narrative never completely overcomes that which came before it. Instead, they tend to coexist. All four narratives are still present in contemporary exhibits, showing a mix of co-existing interpretations of Chileanness. Overall, we see that the exhibition of indigenous cultures has been problematic for national museums in Chile, and in fact it remains so today.

\section{Indigenousness in the Chilean Context}

According to the most recent Chilean Census available (INE, 2012), 11 per cent of the population consider themselves as belonging to an indigenous group. The most numerous group of indigenous people in Chile is the Mapuche (84 per cent), followed by groups from the Atacama Desert (11 per cent), and the Rapa Nui people from Easter Island (0.46 per cent). ${ }^{1}$ Mapuche people (formerly called Araucanos) live throughout the country, mainly in urban areas but also in reservation-style communities. Unlike other indigenous nations in Latin America, the Mapuche were not dominated by the Spanish conquistadores and managed to maintain independence during the colonial period and the first decades of the new republic. They were incorporated into Chile in the late nineteenth century through the so-called 'pacification campaign.' The history that follows is one of discrimination, exploitation and abuse. Only in the 1990s did the Chilean state recognize the country as multicultural. Yet, discourses of multiculturalism have failed to transform into effective cultural rights for indigenous peoples and to this day the Mapuche continue to struggle with the Chilean state for recognition as a nation. ${ }^{2}$

\section{Museums and the Order of Things}

Museum narratives can be understood as systems of classification. Within museums things are labelled and exhibited according to a certain order, which is usually taken as given and even appears 'natural'. In this context, other - usually older - exhibition practices are regarded as messy, confusing, or irrational. And certainly, many of the labeling practices used today to separate collections and explain relationships between objects, will be rendered obsolete in some near future. As sociology has long shown, what counts as true or rational is socially constructed, and therefore is historically and geographically specific to a certain context. Unfortunately, most museum research takes this structure of rationality for granted; in other words, they see relationships between objects, and between objects and subjects, as unproblematic (HooperGreenhill 1992). But if we are to understand knowledge as the product of the museum, then the story of how knowing is enabled, constructed and consumed in museums has to be taken seriously as a field of study. We need to search for the underlying assumptions that inform what counts as true, good or beautiful in museum narratives, and understand how museums contribute to these assumptions in broader culture.

In her book Museums and the Shaping of Knowledge (1992), Eilean Hooper-Greenhill interrogates the history of museums taking this specificity into account. Following Michel Foucault's philosophy of science, she calls for an 'effective history' of museums, in which we assume that rationality and order have historical, social and cultural circumstances (HooperGreenhill 1992). In this account, the differences between things, rather than the similarities, become significant. We should not look for continuities in museum history but rather ask how have things changed and why? And, what is the meaning of these changes? (Hooper-Greenhill 1992: 10).

As philosopher Michel Foucault explained, order is in the core of knowledge. And, in a certain period, we can discern large-scale congruence in this intellectual order. What coincides is not knowledge in itself, but rather an historical a priori that presents the conditions of possibility for knowledge, grounding any finding or event in a web of meaning defined by 
ordering codes (Foucault 1966; 1969; 1980). In Foucault's words:

order is, at one and the same time, that which is given in things as their inner law, the hidden network that determines the way they confront one another, (...) and it is only in the blank spaces of this grid that order manifests itself in depth as though already there (Foucault 1966: $\mathrm{xx}$ ).

It is the relationship between things which constitutes truth in a certain period. This can be seen in different epistemological milieus, and the museum is certainly one of them. The logic of historic museums, for example, only makes sense with the modern episteme, when history and evolution become the dominant ideas governing the organization and display of a collection (Foucault, 1966:263). This rationality is completely different from that of a seventeenth century cabinet of curiosities or a twentieth century scientific museum. The museum, then, is a place for visitors to immerse themselves in 'the order of things,' where truth (according to a certain episteme or period) is exhibited to visitors. ${ }^{3}$

This makes museums disciplinary institutions. They are instances of power (usually state power), exercised through the careful ordering of knowledge (Hooper-Greenhill 1992; Bennett 1995). When exhibiting their collections, museums present a certain truth, or what is believed to be truth at the time, and interpretation is crucial to this production (Lord 2006). Even with no text or no labels, exhibitions constitute an interpretation of the world by giving order to it; some things belong in the museum and others do not, certain objects are exhibited together and others apart. Also, different narratives not only shape the placement of objects but also the ordering of the interiors into major areas (Jordanova 1989). Finally, the museum functions as a decontextualizing context; to place something in a museum changes its very nature. In the museum, the object becomes a concept, a representation of something that it is no longer. Then, it is not that museums exhibit some objective knowledge; instead, they interpret the world in a way that creates (contingent) truth. As Lord masterfully put it - a museum without interpretation can only be a storehouse (Lord 2006: 5).

\section{Museums and National Identity}

When talking about national identity, interpretation can become particularly controversial. Since their origins, nation-states have tended to assume a monolithic and coherent version of nationhood that gives meaning to the culture, values and ways of life of its members. But sociology has long shown that nations are imagined communities, their identities are built by giving meaning to things that are socially constructed (Hobsbawm and Ranger 1983) and utterly contingent (Anderson 1991). As a consequence, there is really no correct way to exhibit a nation, since inasmuch as constructed identities are subjective, they by definition allow for multiple interpretations. In this context, multiculturalism is a challenge for states, and certainly, for state-led museums. Exhibitions and their selective processes contribute to the formation of these imagined communities and their invented traditions. Museums have long contributed to these interpretative narratives by housing (and selecting) what is considered heritage (Bennett 1995; McLean 2007); consequently, periods of increased museum formation have been linked to renewed nationalism (Kaplan 1994; Earle 2007). However, it is also clear that different groups and individuals have varying levels of influence in deciding what constitutes the national community or its traditions (Truillot 1995). This allows for the privileging and suppression of different groups inside the space of the museum (McLean 2007). And it is because of the invisibility of these epistemological forces that they are so powerful.

\section{Indigenousness in Chile's National Museums}

\section{Creating the Nation: Indigenous as Part of the Territory}

In 1830, French naturalist Claude Gay was hired by de facto ruler Diego Portales to explore Chile in the name of science. The contract specifically asked him to write a geographic atlas and, in addition, to form a 'cabinet of Natural History with the principal productions of plants and minerals of the territory' (Philippi 1908: 5). The request sought to symbolically possess the territory, exploring the land that the Chilean state had claimed as its own. This included 
both the Araucanía (at that time occupied by 'unpacified' Mapuche), as well as the Atacama Desert (in dispute with Peru and Bolivia). To know these territories meant, in practice, to chart, classify and order the specimens found there, which was a strategic step for Chile's claims to the land (Sagredo 2009). So we see that, from the beginning, the museum was inseparable from a state agenda of classification and control. Additionally, the National Museum was part of a project to promote the territory as commercially valuable, presenting samples of Chilean animals, plants and minerals. The museum was to advertise Chilean products abroad, and also to display all that was valuable about Chile in order to entice foreign immigrants to settle in the country (Barros Arana 1976; Philippi 1908; Stuardo 1973). Overall, the museum was founded under the premise that the essence of Chile could be found in its natural resources and that a proper representation of this richness would present Chile as a civilized, modern country (Schell 2010).

It was never questioned that indigenous artefacts and bodies formed an integral part of this endeavor. Gay collected widely, and aimed from the beginning to include in his collecting a section of 'Chilean antiques,' gathering the first collection of indigenous artefacts for the Chilean state (Azocar 1999). German zoologist and paleontologist Rudolf A. Philippi, who took office in 1854, extended Gay's collection by requesting donations and organizing new expeditions. He mentions in his history of the National Museum that 'it seems redundant to mention that we possess a large amount of Araucarian objects' (Philippi 1908: 23). He was more enthusiastic about two large stone statues from Easter Island, as well as antiques brought to him from Peru. According to the classification of the National Museum, all of these items became objects of the natural sciences, completely alien to Chileanness. Minerals, plants and 'Indians' where all part of the territory that Chileans had conquered.

As historian Rebecca Earle (2007) has shown, in the initial phase of the war of independence creoles considered themselves heirs to the grandeur of the pre-conquest warriors, but once independence was achieved contemporary indigenous people became irrelevant for nationalism (Earle 2007: 40). Furthermore, the 'pacification' of the indigenous population and the conquest of their territory became a matter of state. On a symbolic level, Earle shows that the 'pacification' campaign was accompanied by increasingly negative assessments of the Mapuche, to the point that any positive mention of them was thought to be unpatriotic (Earle 2007). The National Museum certainly followed these lines. In fact, the Chilean army officially collected for the museum both in the 'pacification' campaign in the Araucanía and in the Pacific War. In 1882, a military expedition to Araucanía was expressly asked to collect indigenous material for the museum, including from excavations of indigenous sites. The orders given to the team stated:

The occupation projected in Araucanía will have as a result the assimilation of the indigenous in their savage form. Soon, the noble Araucarian race will disappear and it will not be possible to study them (...) what we can collect of them now will have great importance in the future (Museo Nacional 1882).

The irony is palpable; there were motives to conserve for future study the very culture they were sent to make disappear. Donald Preziosi has showed the same contradiction in American anthropological museums, in which the foundational aim was to curate and preserve indigenous cultures 'for their own good' before they became extinct (2003: 135). The collection of indigenous artefacts is thus bound up with colonization.

In 1876, the National Museum was moved to its current location in a palace in Quinta Normal Park and later R. Philippi's son, Federico, assumed the role of museum director. In the new building, the indigenous collection had an important role; an 1878 map of the museum shows the ethnographic cabinets occupying approximately a quarter of the museum's total space (Museo Nacional 1878). In the visitor's guide, F. Philippi highlights from these cabinets two Egyptian mummies and a collection of Peruvian and New Zealand antiques (Philippi 1908). The only logic unifying the exhibit is the fact that the objects contained therein come from the exotic, non-Western, non-modern, or uncivilized world. In the museum, indigenous objects are placed in an epistemic order that is Eurocentric and involves the silencing of the voices of those whose traditions are purportedly being presented. Thus, on one hand the museum reflects colonization, and on the other it supports it by presenting the rationality of 
this domination as truth.

Furthermore, decontextualization of indigenous culture involved the exhibition of mummies and skeletons. The first record of a mummy in the National Museum is from 1861. The body came from the Tarapacá region (at the time in dispute with Peru) in the form of a gift from a private explorer (Alegria et al. 2009). Later, the museum collected its own mummies. Phillipi was displeased by the impossibility of collecting mummies from the southern regions, due to weather conditions, but the museum did have skeletons and craniums from Mapuches and Patagones (Museo Nacional 1878). In contrast, the museum never aimed to collect 'Chilean' bodies as they were not considered relevant for scientific endeavours of this kind. Nonetheless, they did come across at least one. Found in the desert and labelled the 'unknown soldier,' $F$. Philippi refused to exhibit him because the body was considered 'sacred' (El Mercurio 1923). The contrast is clear: indigenous bodies are denied their humanity and instead considered objects of science and parts of the natural world, while a 'Chilean' body's humanity comes first, shielding it from objectification. This marks the total submission of the indigenous to modern Chile, the culmination of a bio-political programme of control (Foucault 1980).

Overall, the exhibit at the National Museum considered the indigenous population as part of the territory that Chilean people had conquered and were entitled to explore (and exploit). Just as minerals and plants were especially interesting when they came from previously unexplored areas of the country, indigenous cultures should similarly be explored because of their oddity. In line with this thinking, the museum was a place to exhibit war trophies. The Pacific War and the occupation of the Araucania region were crucial to the collection. The museum then projected a view of Chile as a regional power, associating Chileans, as museum visitors, with the scientific eye of enlightened [sic] Europeans (Schell 2010) (Alegria et al. 2009). As an article in the museum's bulletin clearly expressed: 'since the Conquest, the number of indigenous has been retreating little by little and the population of our fatherland is formed mainly by white elements, also called Caucasian' (Quijada 1911). In the museum, Chilean elites assumed European ordering codes as their own and positioned themselves as akin to Europeans in their search for the exotic and uncivilized savage.

\section{Exalting the Nation: Silence in Art}

By the end of the nineteenth century, Latin American countries experienced accelerated museum formation in line with a renewed elite nationalism. According to Earle (2007), the ruling classes no longer perceived natural history as constituting 'national' history and they had shifted their focus toward wanting to tell the stories of human achievements (meaning, their own achievements). In Chile, this trend led to different exhibition projects, and then finally to two new national museums. The first was the National Museum of Fine Arts. For artists and critics in Chile, art was as crucial for national development as a sound economy (Schell 2000) (Hernandez 2006). The Academy of Paintings had been created in 1849 and an Academy of Sculptures in 1854, but there was no permanent public exhibition of art in the country. Upset by this situation, a group of elite men began a campaign to convince the government that art was crucial for the country's reputation; Santiago was meant to be the continent's cultural capital (Schell 2000). They succeeded, and the National Museum of Fine Arts (Museo Nacional de Pinturas, renamed later Museo Nacional de Bellas Artes) was founded in 1880.

But, as with the previous narrative, the nationalist sentiment articulated by these men did not accept the majority of the states' population as fellow nationals; the indigenous did not count (Earle 2007). In the art sphere this was most extreme; indigenous cultures were simply invisible. According to museologist Patience Shell (2000), during this period Chileans started to claim a racial advantage among Latino nations; they believed the Pacific war confirmed their superiority over their more mestizo (racially-mixed) neighbours. Accordingly, the Museum of Fine Arts was neither the product of self-discovery nor an innovative art project, but rather a stylized notion of Chileanness based in the European paradigm (Hernandez 2006). The collection presented an eclectic mixture of originals and copies of old masters, as well as some modern pieces recently purchased in Europe (Schell 2000). In terms of Chilean art, landscapes were prominent, accompanied by notable works of popular Chilean culture and some historical paintings. Although considered a low form of art (compared to historical painting), depictions of light in the mountains and fecund fields were valued by the Chilean public because they 
represented 'our Chile' (Schell 2000). It was, in Schell's words, 'such an exaggerated imitation of things European as to become a parody' (Schell, 2000).

Under this view, the indigenous were present only as a theme, and very rarely. The catalogue of 1896 shows only three works that depict indigenous people. Sculptor Nicanor Plaza immortalized the famous tribal chief Caupolicán wearing a crown of feathers, big earrings and skirts; a look that had nothing to do with Mapuche culture. In truth, Plaza used as a model a Caucasian man, which was considered the standard of beauty. Then, to make it look 'Indian' he appealed to a general sense of indigenousness that European schools of art sought (Zamorano 2011). This is, of course, only one piece in the museum, but it is almost the only one representing the indigenous to this day. Very few works of art portraying the indigenous world have been added since, and none of indigenous art itself. Not to the exhibit and not to the collection. ${ }^{4}$

It is true that indigenous artefacts have not always been viewed as art by the western world, but sometime in the 1970s art museums around the world began to collect these objects. In some countries, this collection was associated with a strong debate over where these objects should be exhibited (Colburn 2005). But in Chile, the National Museum of Fine Arts has still not made this transition; even today their collection of Chilean art does not include any indigenous artefacts (Museo Nacional de Bellas Artes 2009).

\section{Narrating History: The Indigenous as People from the Past}

As mentioned before, by the end of the nineteenth century Latin American countries experienced a 'museum fever' that, in Chile, translated into different exhibition projects, and then finally culminated in the creation of a permanent history museum. The first experiment was the Exhibition of the Colonial Period (Exhibición del Coloniaje), in 1873. Santiago's Mayor Benjamín Vicuña-Mackenna resolved to exhibit the 'history of our national existence' by displaying objects chronologically, 'grouping the objects logically and classifying them in a pertinent way' (Vicuña-Mackenna 1873a: 342). With this, Vicuña-Mackenna inaugurates a new era in museum narrative; the 'order of things' completely changed from this point on. If in the National Museum things were arranged in terms of taxonomy, with objects being classified according to their identities, in the new History Museum things are positioned according to a temporal variable. Evolution and history become the main ideas organizing the display. In this scheme, the indigenous are recognized as people from Chile's past. Under this view, preconquest history is only a prelude to real history (Crow 2009). In effect, it was important for Vicuña-Mackenna that the indigenous be relegated to the pre-conquest period, and objects to be exhibited had to be authenticated as such. The Colonial Exhibition was an enormous success; when it was over, the idea of creating a permanent history museum was strong but not yet strong enough to materialize. ${ }^{5}$

It was a number of years later that a group of congressional representatives presented a formal request to create a historical museum for the centennial celebrations of the Republic. But the museum could not be completed before the 1910 celebrations. Instead, the Historic Exhibition of the Centennial Celebrations (Exposición Histórica del Centenario) opened on September 21, 1910. Just as occurred with its predecessor exhibition, indigenous artefacts were to be presented in the first of 15 chronological sections, reserved to the pre-colonial period. ${ }^{6}$ When the centennial celebrations were over, the organizers asked for a permanent museum of history that would conserve the collection that had been gathered in conjunction with the development of the exhibitions. Finally, a National Museum of History was established in 1911. Organized in five rooms on the first floor of the new building of the National Museum of Fine Arts, the new museum gathered all of the collections that had been dispersed after the exhibitions had been dismantled. Its aim was:

to exhibit the history of Chile starting with our most remote ancestors from the Stone Age to the aboriginals found by the Spaniards when they discovered Chile, and also, the Spanish Conquest, the Colonial years, Independence and the Republic until the present day (Congreso Nacional de Chile 1911).

But it was not until 1929 that the museum managed to gather all of its purported collection in one place. Initially, the ethnographic collection had a museum of its own. 
As mentioned before, the indigenous were present in the new National Museum of History through the 'Prehistoric Section,' following the narrative inaugurated by Vicuña-Mackenna's exhibition. The first curator of this section was German archaeologist Max Uhle. But because there was not enough space (or interest) to store the indigenous collection in the museum, Uhle and his collaborators organized a museum of their own, the short-lived Ethnologic and Anthropological Museum (Museo de Etnología y Antropología) (Alegria 2004). Anthropologists at the museum opposed mainstream ideas that classified the indigenous as part of the natural world. They valued indigenous cultures and wanted to protect their legacy, lobbying diligently for a law to govern the extraction of archeological objects in Chile. However, they too believed their disappearance 'under the levelling waves of modern culture' to be inevitable (Gusinde 1906: 17). Following the historical paradigm, the museum's bulletin constantly refers to the indigenous as 'pre-historical' and it focuses on studying indigenous communities that no longer existed at that time, such as the Inca. The anthropological museum, although an interesting and important intent to value indigenousness, was still very much a part of a past-tense narrative.

In 1916, the new director of the National Museum, Eduardo Moore, requested that the government officially transfer the prehistoric collection entirely to the museum, which meant the closing of the anthropological museum (Gusinde 1906: 4). The objective of the National Museum had been specified by law in 1910 as to 'preserve the fauna, flora and soil of the country' (Museo Nacional 1910: 207). There was no mention of an anthropological section; still, an Anthropology department was started in 1912. In response to the request made by Moore, anthropologist Aureliano Oyarzún defended the independence of the Anthropological Museum, arguing that:

the museum at Quinta Normal cannot continue to be referred to as Museo Nacional; if the reason for its original name was the fact that it was the only one in the country, once the history, anthropology and ethnology sections are removed it will truly become the Natural Sciences Museum, and therefore, its original name is unjustified (Gusinde 1906: 4-5).

He added that 'if we must transfer the collection, it should be to the History Museum.' A debate was sparked for the first time in the minds of Chile's intellectuals and academics: are indigenous people a part of the natural sciences or part of Chilean history? By tracing the fate of the collection at the Anthropological Museum, we find the answer arrived at by the Chilean state.

A Division of Libraries, Archives and Museums was created in Chile in 1929 (DIBAM). By law, the National Museum of History was given the mission to:

Gather all objects relating to national history, both civil and military, along with Chilean environment and customs from different epochs. In its prehistoric section, the collection will be limited to the Chilean aboriginals, constituting the base and preference for this collection in the country (Congreso Nacional de Chile, 1929).

Similarly, the National Museum was now officially the National Museum of Natural History, with the mission to:

Gather all Botanic, Zoology, Geology, Mineralogy, Paleontology, Anthropology, Ethnology and Archeology that are universal. It will include in its anthropological, ethnological and archeological collections the 'Chilean man'; but the base and preference for Chilean pre-historical artifacts will remain in the National Museum of History (Congreso, 1929).

Hence, no definitive answer was provided to the question of where to exhibit the indigenous and the collection of the Anthropological Museum was divided. ${ }^{7}$ (Also, it is important to highlight that, by law, from this moment on the indigenous were officially declared to be 'prehistoric'). In the National Museum of History the exhibition was once again organized chronologically, with the indigenous cultures relegated to the first room. But now the Mapuche were recognized as especially relevant for this historical exhibition. According to historian Joanna Crow (2009), warfare has always had a central place in the imaginary construction of the Chilean nation 
and this led museum curators and others to assign the Mapuche a greater role in Chilean history than other indigenous peoples, simply because they never surrendered to Spanish conquerors (or to the Chilean state, though this distinction is never highlighted). Accordingly, a review of the museum in 1947 describes that:

The silhouette of a Spanish soldier dominates the room. $(\mathrm{He})$ is surrounded by different weapons....all the instruments of war on which the Spanish soldier depended to dominate the naked Indians, armed only with arrows made of bamboo, but the (latter's) courage and love of freedom was more effective than all this arsenal (Crow 2009:113).

Overall, the script followed by the museum exalted the vanquished Mapuche as brave and noble, but never doubted that they should be vanquished. The museum was clear in expressing that their 'primitive' customs were displaced by Spanish culture. Contemporary Chile was the culmination of this civilization process; the Mapuche were praised for their bravery, but discarded as an obstacle to development. Most remarkably, in the museum the heroic feats of the conquistadores (i.e. to discover and conquer Chilean territory) became the feats of the Chilean nation (Crow 2009). 'It would seem then, that the Araucarian victory against the invaders was only a minor setback in the grand scheme of things: it did not prevent Chile becoming a successful colonial endeavour, it did not prevent it becoming Hispanicised' (Crow 2009).

This narrative was only reinforced when the museum acquired its final building in 1983, in the middle of Augusto Pinochet's dictatorship. The 1970s was an agitated period in Chilean political history, to say the least. Yet, the museums were not greatly affected by the turmoil. The socialist government of Salvador Allende (1970-73) had a strong influence in the cultural sphere, rethinking Chilean identity outside the limits set by the elite, but it had no time to focus on or play an active role in the national museums. After the coup d'état of 1973, the military Junta tried to regain control over the areas they saw as distinctive of Chileanness, which meant rediscovering the old masters of Chilean painting, establishing a strong cult defined by national symbols, and controlling the musical sphere (a field where Allende's Unidad Popular had had a strong influence). But the National Museums presented little threat to the Junta's views; the National Museum of History's narrative in particular was already heavily Europeanized (and militarized) and the National Museum of Fine Arts only exhibited European works and 'masters of Chilean art'. Still, it is worth mentioning that most of the pre-historic collection was sent back to the Museum of Natural History (formerly the National Museum) in order to 'make room for collections more related to the Chilean nation' (Mostny 1975). The Mapuche were the only indigenous group present in the museum; represented as heroic indomitable warriors struggling against the conquistadores. In conclusion, the military regime did not create a new narrative, but rather reinforced the conservative, romanticized version of Chileanness that the National Museum of History had already established. An exhibit that sought to present republican Chile as the fulfillment of the Spanish project and history is seen as manifest destiny; the Mapuche's successful resistance against the Spanish army is praised but at the same time considered only an obstacle in the path to development.

Finally, it is important to highlight that this new narrative did not mean that the old narratives were set aside altogether. From the early twentieth century onward, the National Museum of Natural History continued to organize expeditions to 'virgin' territories. In 1915, they looted Mapuche tombs in order to measure the bones, with strong opposition from the indigenous community. In 1922, an earthquake made visible an unknown indigenous cemetery in Atacama, and it was representatives from the National Museum of Natural History that were sent to collect the pieces. By 1941 a report on anthropology in Chile named the National Museum of Natural History as having the best anthropological collection in the country (Brand 1941), with most of the objects remaining there regardless of what the law said.

\section{Re-interpreting the Nation: Mestizaje}

In 1990, the country overcame 16 years of dictatorship, and the new government had a different view on indigenousness. The new center-left government coalition declared their willingness to include the indigenous population in contemporary politics and social development, and in 1991 a commission for indigenous education and culture was created. In 1993 the indigenous 
population received official and legal recognition through the 'Indigenous Law'. ${ }^{8}$ This law regulated the commercialization of indigenous artefacts, established the National Corporation for Indigenous Development (CONADI) and directed government programs to assist with the development of indigenous communities. Evaluations of these policies have not always been positive; nonetheless, it is a fact that from this point on the indigenous population was formally acknowledged as present and a part of the country. What happened in the museums?

Once again, the museum that suffered the most change was the National Museum of History. Historian Sofía Correa Sutil was appointed Director; she revised the entire museum exhibition with the goal of conveying a far more inclusive version of Chileannesss. She wanted to make the museum a forum for debate, including the possibility of having multiple interpretations of historical events. With this in mind, she brought together roughly 20 Chilean academics to discuss the reforming of the museum and its exhibition. In this process, she pushed for indigenous people to be represented as a fundamental part of the Chilean nation. She stated that 'the exhibition must emphasize the essential integration of indigenous peoples into national history. They cannot be confined to the pre-conquest period' (Correa Sutil 1994). Correa Sutil went ahead with her plans with no monetary support from the government. Even though multiculturalism had been promoted by the new government in discourse and through laws (Ley 19253, 1993), the museum was not seen as an important field for this recognition. She also faced criticism from a number of Chilean historians who supported a more conservative view of Chilean history. Nonetheless, the new narrative did revise the role given to the indigenous people in the museum, assuming Chileanness to be an 'encounter of two races' yielding as a result 'a new reality, different from the previous ones, although descending from them' (Correa Sutil 1994: 18).

The 'Indigenous Room' (Sala Indigena) replaced the 'pre-history' room in 1996. In this room different indigenous artefacts are exhibited, such as a rewe (sacred altar) from the Mapuche people and several pieces of ceramics from the northern cultures. Besides the change in name, the new display emphasizes mestizaje (blending of 'races') as playing a key role in Chile's history and development. Labels relate indigenous culture with Chilean food and language, including -for example- the display of a typical Chilean rural house, highlighting the mixed elements. At the same time, the Indigenous room displays elements created by the indigenous groups but with clear Spanish influences, for example a poncho. In the next room, still called La Conquista (Conquest), Mapuche weaponry was added to the display of Spanish arms and the text was re-written to emphasize that the Mapuche fought a stalemate with the Spanish. Furthermore, in the 'Independence Room' the visitor learns that the concept of Chileannesss was invented by the ruling elite and has experienced great change throughout Chilean history, itself suggested as a social construct by the interpretative panels accompanying the display. Chileanness, according to the signs in the room, is a social construct.

This certainly is a great step toward a modern view of nationhood, one that includes different possibilities to be part of one 'imagined community" (Anderson, 1983). However, as historian Joanna Crow has highlighted in her study of this museum, the process of nationbuilding is presented here as fairly unproblematic (Crow 2009). For example, there is no discussion of the occupation of Araucania by the Chilean state in the eighteenth century, nor any mention of the resistance of Mapuche people to mestizaje and assimilation. In the small section dedicated to this part of Chilean history that exists in the museum (in the middle of a room almost fully devoted to the Pacific War), the panels that originally talked about the 'pacification of Araucanía' were only recently changed to 'occupation'. To this day, the museum's graphic explains that: '[Chileanness] became more inclusive as the nineteenth century wore on; through processes such as war, in which marginalized classes participated as soldiers, all inhabitants of the country were transformed into Chileans; subaltern groups felt included and did not question the new order' (Crow 2009:119). As we can see, the nation is taken as a monolithic, coherent thing; mestizaje and assimilation is assumed to be complete and the presence of indigenous communities in contemporary Chile is ignored. Furthermore, in the museum we learn nothing about indigenous culture in this century. In a small niche we see different indigenous artefacts. Why is a drum relevant to the occupation of the Araucanía? We cannot tell from the exhibition graphics and display.

Furthermore, although the indigenous are now more present than ever before in the 
history of the museum, the exhibit is still strongly chronological and the Mapuche are continuously referred to in the past tense; events are written from a dominant Spanish perspective and we learn nothing about how the Mapuche live today. They are somehow portrayed as passive victims of history and Chilean history as 'manifest destiny'. In the exhibit, we seem to be looking for their traces, but never looking for them. In this sense, with regards to acknowledging Mapuche communities remaining in Chile, the mestizaje narrative is not very different than the prehistoric narrative.

\section{Conclusions}

This review of the practices of exhibiting indigenousness in Chile's national museums shows from a nontraditional perspective how complicated the relationship between the Chilean state and indigenous communities have been, particularly with respect to the Mapuche. The examination of these exhibition practices over time shows that while the Mapuche's brave history has been key to Chilean national museums, they tend to trace Chileanness to Europeans, circumscribing the indigenous as part of the territory, people of the past or emphasizing mestizaje. The idea of Chile as a non-indigenous country has been an important part of the ideological apparatus of Chilean elite, and all three museums were organized by elite men trying to display Chile's grandeur to Chileans as well as to those elsewhere. This attitude underpinned efforts to present the idea that Chile was more developed and western than its neighbours, assuming that such character was necessarily related to a lack of indigenous population. Also, not only was the museums' collection formed in part with stolen artefacts, but the misappropriation of cultural objects to be presented based on European ordering codes involves another kind of theft. This issue is one that all four narratives share: their Eurocentric understanding of Chilean history and consequent silencing of the fact that there are still indigenous people in Chile resisting assimilation can be seen as a mode of colonization.

Nonetheless, we can see a trend over time toward acknowledgement of the indigenous as part of Chileanness. The first narrative described in this paper understood the 'Indian' as something that was absolutely strange to Chileans. The second narrative recognizes the indigenous population as related to the Chilean nation, even though the relationship is marked by the territory and little else. The third narrative is by far the most inclusive; not only understanding the indigenous as part of Chilean history but also as part of the Chilean present, even if only through existing customs, food and language. And the fact remains that, although consecutive in their emergence, we find all three of these orderings present in the museums today. According to Hooper-Greenhill (1992), one of the ways to uncover the history of truths is to focus on the history of errors. But in the case of this history, errors have never been 'fixed' by new narratives. Instead we found new museums, or new museum's schemes sharing the space of the museums of the country, but not replacing old structures of knowledge. New relationships and new articulation have appeared, but everything described here can be still found somewhere in Chile's national museum. And today indigenousness is scattered in museums across Santiago with no common narrative.

What a visitor to Santiago will find is that Chile's National Museum of Natural History continues to have a broad collection of indigenous artefacts and mummies on display. Even after restoration in 2010 , the museum did not change its name, narrative, or organization. That is, the same structure of knowledge remains in place. The anthropological and natural science sections remain unseparated inside the museum. The exhibit is instead organized by geographical area. For each region of the Chilean territory we see rocks, animals, plants and indigenous tribes exhibited as a coherent whole, they 'belong" to this or that region. This order emphasizes a narrative of the indigenous as part of the territory, something that Chileans have conquered and made their own.

Since its foundation, the National Museum of Art has continued to present a view of Chilean Art as an emulation of European art history, and does not have a section of Chilean indigenous art to date, nor does it include the work of indigenous people in its Chilean section. ${ }^{9}$ Additionally, it started a collection of African indigenous art long ago, which completely contradicts the possible argument that the museum is dedicated exclusively to European art. Conclusively, the narrative in this museum, where the indigenous are not represented at all, 
simply does not consider the indigenous to be a part of the Chilean nation.

Finally, the Historical Museum today is beginning a renovation process which includes rethinking its narrative. In particular, the role of the indigenous is one of the points the museum has contemplated changing. ${ }^{10}$ But for now, a visitor to the museum only sees indigenous artefacts in the first room of a strict chronological ordering; the name of the room following the new 'Indigenous Room' (formerly the pre-historic room) is still called 'Discovery and Conquest.'11 Overall, we see that although it now treats the indigenous with greater respect and deference, the narrative still links what it means to be Chilean with its Spanish ancestors. We also see that narratives of mestizaje have not altered the historical order. For example, information about the Mapuche and their communities today is still wanting. We learn nothing about their strategies during the occupation, the political disputes in the Mapuche community, or anything else from their point of view. True, this point of view has recently been acknowledged in the Mapuche Museum of Cañete (Crow 2011), a local initiative only recently incorporated to the DIBAM system. And as the name shows, the museum is located in Cañete, in the traditional Mapuche territory, $635 \mathrm{~km}$ from Santiago and the national museums. Also, the exhibition does not consider Mapuche people as related to Chileanness, but as an 'other' (Crow 2011).

The most significant problem is that all four narratives force a monolithic view of Chileanness. That is, they assume that there can only be one way to be Chilean, and that we need only agree as to what this one way is. Chileanness has changed to become more inclusive, but it continues to suppose a common identity for all Chileans, and only one Chilean nation. As a consequence, the only way the indigenous -or any other minority group - can find a place in the single nation is by assimilating into it. Until a narrative emerges that comprehends Chile as a multi-national or multi-ethnic society, and such narrative becomes present in the public sphere, it will be difficult to find a place for the indigenous in a Chilean National Museum.

Received $2^{\text {nd }}$ March 2015 Finally accepted $23^{\text {rd }}$ November 2015

\section{Notes}

1 The 2012 Chilean Census has been extensively critiqued and will be repeated in 2017 (See: Report of the International Commission on the 2012 Population and Housing Census of Chile. http://www.ine.cl/). Nonetheless, the indigenous population in Chile is believed to be approximately eight to ten per cent of the total population (IDB 2014. Contando la población indigena de Chile. http://idbdocs.iadb.org/wsdocs/getdocument. aspx? docnum=39334376).

2 For a discussion of the Mapuche's controversial history with the Chilean state see: (Salazar 2005; Pinto Rodríguez 2005).

3 Because they are inherently ordering codes; Foucault considers museums heteropias, a space of difference. "The museum not only represents objects that are different from one another, it represents objects in their difference from the conceptual orders in which those objects would normally be understood' (Lord 2006: 5).

4 Catalogues were found for the years 1896, 1922, 1938 and 2010. The last catalog of the MNBA shows no new acquisition in this regard since the 1896 catalog. Indigenous art is simply not considered art for this museum.

5 The Exhibition of the Colonial Period also included an undetermined number of live Patagones and Fueguino people brought from Tierra del Fuego (Alegria et al. 2009). It is not clear how these people became part of the exhibition. Apparently, they were sent by the governor of Tierra del Fuego, who captured them after they tried to 'eat' some shipwrecked sailors (El Mercurio de Valparaiso 1873). But they are not mentioned in the exhibition's catalog or in Vicuña Mackenna's accounts of the event. Apparently they were an afterthought, added at the last minute and not constituting part of the exhibition per se. Nonetheless, they served to contrast the Spanish civilization that was being praised in the exhibition with the savage, to show what Chile might have been if not for the arrival of the Spanish (Alegria et al. 2009; Schell, 2009). 
6 Unfortunately, there is no catalog for this exhibition and information about it is scarce. Thus, it is unclear whether indigenous objects were in fact gathered and exhibited (Alegria and Nuñez 2007).

7 The majority of the collection of objects such as pottery, carved stone and jewelry was sent to the National Museum of History. Skeletons and mummies were sent to the National Museum of Natural History (originally the National Museum).

8 This law recognized the Mapuche people in particular as an inherent part of the Chilean nation. Other indigenous people officially recognized included the Aymara, Atacameña, Colla, Quechua, Rapa-Nui, Yámana, Kawashkar and Diaguita (some of these categories have since been changed).

9 The museum has indeed, presented indigenous art in temporary exhibits. Mostly, these artefacts have come from the Museo Chileno de Arte Precolombino (Chilean Museum of Pre-Columbian Art). The museum is a private non-profit and not a part of DIBAM, holding a broad collection of indigenous artefacts from all over Latin America.

10 Also, for the new museum chronology will no longer be so important. Instead, different processes that constitute the Chilean nation will be highlighted in parallel. This, unlike the mestizaje narrative, promises to be a true change in paradigm (from private conversations with museum officials).

11 In the project to modernize the exhibition the use of the term 'Discovery and Conquest' was discussed. Correa Sutil was conscious that the category was 'questionable' but she argues that it is at the same time 'broadly used since Chilean history began to be written.' She opts for 'problematizing the period' instead of changing its broadly used name (Correa Sutil,1994: 18).

\section{Primary Sources}

Congreso Nacional de Chile (1911) 'Decreto 1,777' Santiago: Actas del Congreso Nacional de Chile.

(1929) 'Decreto con Fuerza de Ley 5200', Santiago: Ministerio de Educacion Publica.

El Mercurio de Valparaiso (1873) 'El Antropófago', El Mercurio de Valparaiso, 23 September, 2-3.

(Santiago) (1910) 'La Esposición Histórica del Centenario', March 21st

(Santiago) (1923) 'Algo más sobre los restos del soldado desconocido', 31 January.

Museo de Etnología y Antropología de Chile (1924) 'Catálogo de la colección de objetos del Folklore Chileno'

(1927) Memoria Presentada al señor Ministro de Instrucción pública por el Director del Museo de Etnologia y Antropología

Museo Nacional (1878) 'Guia del Museo Nacional de Chile en Septiembre de 1878', Santiago: Imprenta del Estado.

(1882) ‘Envió de una comisión científica a lo interior de la Araucanía’ Anales de la Universidad de Chile. Santiago: Universidad de Chile. 
(1910) 'Memoria presentada al Sr Ministro de Instruccion Publica por el director del Museo Nacional', Boletin del Museo Nacional de Chile, II

(1916), 'Las Colecciones existentes en la sección de Antropolojia i etnolojia del Museo Nacional' Boletín del Museo Nacional de Chile. IX. Pp: 134-140

Museo Nacional de Bellas Artes, (2009), Centenario: Colección Museo Nacional de Bellas Artes, 1910-2010, Santiago.

Oficina Nacional de Estadistica, (1909), Anuario estadistico de la Republica de Chile. "Museo Nacional, Santiago" P: 533-540

\section{References}

Alegria Licuime, L. (2004), 'Museos y campo cultural: Patrimonio indigena en el Museo de Etnologia y Antropologia de Chile', Conserva, № 8. 57-70.

Alegria Licuime, L et al. (2009) 'Momias, cráneos y caníbales. Lo indígena en las políticas de exhibición del Estado chileno a fines del siglo XIX', Nuevo Mundo, Mundos Nuevos. http://nuevomundo.revues.org/53063.

Alegria Licuime, L. and Nuñez, G. (2007) 'Patrimonio y Modernizacion en Chile (1910): La exposicion histórica del Centenario', Atenea, 495, 69-81.

Anderson, B. (1991) Imagined Communities, London: Verso.

Azocar, M. A. (1999) ‘Don Claudio Gay y la primera coleccion antropologica chilena', Revista Museos, 23, 12-16.

Barros Arana, D. (1876) Don Claudio Gay, su vida i sus obras, Santiago: Imprenta Nacional.

Bennett, T. (1995) The Birth of the Museum: History, Theory, Politics, New York: Routledge.

Brand, D. (1941) 'The Status of Anthropology in Chile', New Mexico Anthropologist, 5 (3) 55-71.

Colburn, F. D. (2005) 'From Pre-Columbian Artifact to Pre-Columbian Art', Record of the Art Museum, 64, 36-41.

Correa Sutil, S.(1994), Proyecto de modernización del Museo Histórico Nacional, Santiago: Museo Historico Nacional.

Correa Sutil, S. (2000) 'Un historiador no puede permitir la amnesia', Revista Rocinante,18.

Crow, J. (2009) 'Narrating the Nation: Chile's Museo Historico Nacional', National Identities, $11(2)$.

(2011) 'The Mapuche Museum of Cañete (1968-2010): Decolonising the Gaze', Journal of Latin American Cultural Studies. Vol. 20, No. 2, pp. 161-178.

Earle, R. (2007) The Return of the Native: Indians and Myth-Making in Spanish America, 1810-1930, Durham, NC: Duke University Press.

Fernandez, E. (2011) 'Cultura politica y conmemoracion patriotica: el primer centenario de la independencia de Chile (1910)', DOSSIER, (86) 71-98.

Foucault, M. (1966) The Order of Things: An Archaeology of the Human Sciences, New York: Pantheon Books. 
(1969) The Archaeology of Knowledge, Paris: Gallimard.

(1980) Power/Knowledge: Selected Interviews and Other Writings, 1972-1977, New York: Pantheon Books.

Galindo Castro, L. A. (2005) 'Museums, Knowledges and Cultural Diversity in Venezuela', MUSEUM International, 57 (3) 60-69.

Garcia Canclini, N. (1990) Culturas híbridas: Estrategias para entrar y salir de la modernidad, Mexico DF: Debolsillo (Random House Mondadori).

González de Oleaga et al. (2011) 'Looking from Above: Saying and Doing in the History Museums of Latin America', Museum and Society, 9 (1) 47-76.

Gusinde, M. (1906) 'Prologo: El Museo de Etnologia y Antropologia de Chile', Publicaciones del Museo de Etnologia y Antropologia de Chile , 1.

Herle, A. (1997) 'Museums, Politics and Representation', Journal of Museum Ethnography, 9, 65-78.

Hernandez, C. (2006) 'Galerias del Progreso: Museos, exposiciones y cultura visual en America Latina', in Viterbo, B (ed) Museos, exposiciones y cultura visual en América Latina, 261-294, Estudios Culturales.

Hobsbawm, R. and Ranger, T. (1983) The Invention of Tradition, Cambridge: Cambridge University Press.

Hooper-Greenhill, E. (1992) Museums and the Shaping of Knowledge, London: Routledge.

INE, 2012. Sintesis de Resultados, (Report), Santiago de Chile: Instituto Nacional de Estadisticas.

Inostroza, I. (1998) 'Etnografia Mapuche del siglo XIX', in Fuentes para el historia de la Republica. Santiago: Direccion de Museos y Bibliotecas de Chile, 7.

Jordanovia, L. (1989) 'Objects of Knowledge: A historical perspective on Museums', in Peter Vergo (ed.), The New Museology, Reaktion Books, London, 22-40.

Kaplan, F. (1994) Museums and the Making of 'Ourselves': the role of objects in national Identity. Leicester: Leicester University Press.

Lord, B. (2006) 'Foucault's museum: difference, representation and genealogy', Museum and Society, 4 (1) 11-14.

McLean, F. (2007) 'Museums and the Construction of National Identity: a review', International Journal of Heritage Studies, 3 (4), 244-52.

Mostny, G. (1975) Los Museos de Chile, Santiago de Chile: Editorial Gabriela Mistral.

Murphy, B. (2005) 'Memory, History, and Museums', Museum International, 57(3) 70-8.

Philippi, R. (1908) 'Historia del Museo Nacional de Chile', Boletin del Museo nacional, I, 4-30.

Piaget, J. (1968) Structuralism, New York: Harpe.

Pinto Rodríguez, J. (2005) 'La Formación del Estado y la Nación y el Pueblo Mapuche' Santiago de Chile: Centro de Investigacion Barros Arana. 
Preziosi, D. (2003) Brain of the Earth's Body: Art, Museums, and the Phantasms of

Modernity, Mineapolis: University of Minnesota Press.

Quijada, B. (1911) 'Catalogo llustrado i Descriptivo de la colecion de mamiferos vivientes' Boletin del Museo Nacional, I(8)139-40.

Sagredo, R. (2009) 'Geografía y nación. Claudio Gay y la primera representación cartográfica de Chile', Estudios Geográficos, LXX, 231-67.

Salazar, G. (2005) Construcción de Estado en Chile (1760-1860): democracia de 'Los pueblos' militarismo ciudadano golpismo oligárquico, Santiago: Editorial Sudamericana.

Schell, P. (2000) 'High Art and High Ideals: the Museo Nacional de Pintura and the development of the art in Chile, 1879-1890', http://www.bbk.ac.uk/ibamuseum/texts/ Schell02.htm.

(2009) 'Exhuming the Past with the Future in Mind: History Exhibitions and Museums in late nineteenth-century Chile', http://www.bbk.ac.uk/ibamuseum/texts/Schell03. htm.

(2010). 'Capturing Chile: Santiago's Museo Nacional during the Nineteenth Century', Journal of Latin American Cultural Studies, 10, 45-65.

Sepulveda dos Santos, M. (2005) 'Representations of Black people in Brazilian Museums', Museum and Society, 4(1) 51-65.

Sleeper-Smith, S. (2009) Contesting Knowledge. Museums and Indigenous Perspectives, Nebraska: University of Nebraska Press.

Stuardo, C. (1973). Vida de Claudio Gay. Escritos y Documentos, Santiago: Editorial Sacramento.

Trampe, A. (2007) 'Museos de Chile: Una unión esperada', Revista Museos, (25) 2-4.

Trouillot, M. (1995) Silencing the Past: Power and the Production of History, Boston: Beacon Press.

Vicuña Mackenna, B (1873) Catalogo razonado de la Esposicion del Coloniaje celebrada en Santiago de Chile en Setiembre de 1873 por uno de los miembros de la comision directiva, Santiago de Chile: Imprenta del Sud-America, de Caro y Salinas.

(1873). 'La Esposicion del Coloniaje', Revista de Santiago,

Zamorano, P. E. (2011) 'Nicanor Plaza y Francisco Gazitúa: dialogo en torno a El Caupolicán', Aisthesis, 49, 84-100.

${ }^{*}$ An earlier version of this paper was presented at the 82rd Annual Meeting of the Eastern Sociological Society in New York (2010) and at the 1st Public Sociology Conference at George Mason University, VA (2010). Thanks to Nan A. Rothschild, Karen Barkey and the people at the Columbia Sociology Practicum for the helpful comments.

*Magdalena Gil is a Phd candidate at the Department of Sociology of Columbia University in the city of New York. She gained her training as a sociologist at Universidad Catolica de Chile, where she taught as adjunct from 2008 to 2009. Later, she earned both an M.A and M.Phil in Sociology from Columbia University, where she also participated in the museum studies 
program. Her research interests include material culture, its conservation and disappearance; catastrophes and their consequences for social life; and Latin American nationalism and state building. She is currently finishing her dissertation on the effects of earthquakes in Chilean history.

Postal Address: 126 4th Avenue, \#2A, Brooklyn, NY 11217

Telephone number: 1 (415)735-8180

Fax number: 1 (212) 854-9099

Professional Address:

Department of Sociology

Knox Hall,

606 West 122nd Street,

MC 9649,

New York, NY 10027

email: msg2144@columbia.edu 